Kamil Trombik

\title{
Wyjątkowy status człowieka w przyrodzie? Nauki ewolucyjne \\ a chrześcijańska antropologia
}

Chociaż spór o rozumienie człowieka toczy się od przeszło dwudziestu stuleci, na sile przybrał zwłaszcza w drugiej połowie XIX i na początku XX wieku. Obok filozofii „mistrzów podejrzeń” (Ludwig Feuerbach, Karol Marks, Friedrich Nietzsche, Zygmunt Freud) kształtował się w tym czasie paradygmat ewolucyjny, który zdawał się równie mocno - choć z zupełnie innej perspektywy - kwestionować dominujace w zachodniej kulturze podstawy biblijne i filozoficzne antropologii chrześcijańskiej. Obecnie, gdy syntetyczna teoria ewolucji cieszy się w zasadzie powszechna akceptacją w gronie uczonych, przed teologia rysują się dodatkowe trudności, wyrastające zwłaszcza z aplikacji ewolucjonizmu do nauk o umyśle, moralności czy religii. Sprawia to, że pytanie, czy można zintegrować naukowy obraz ewolucji gatunku Homo sapiens z orędziem tradycji judeochrześcijańskiej o człowieku, wciąż pozostaje otwarte.

Antropologia chrześcijańska bazuje przede wszystkim na esencjalistyczno-kreacjonistycznej koncepcji człowieka, wywodzącej się z tradycji biblijnych, patrystycznych oraz metafizyki arystotelesowsko-tomistycznej ${ }^{1}$. Według tego ujęcia istota ludzka jest rozumiana jako osoba (gr. прóбமпоv, łac. persona), tj. cielesny byt obdarzony

1 Zob. np. J. Warzeszak, Człowiek w obliczu Boga i pośród stworzenia, Warszawa 2005, s. $62-91$. 
duchową i nieśmiertelną dusza, której naturalnymi władzami są rozum oraz wolna wola, orientujące człowieka na istniejące niezależnie od uwarunkowań podmiotowych wartości poznawcze (prawda), etyczne (dobro) i estetyczne (piękno). Teologowie uważaja, opierając się na źródłach biblijnych, że w naturę osoby wpisana jest godność, świadczacca o wyjątkowej pozycji człowieka w przyrodzie. Przyjmuje się, że istoty ludzkie zostaja stworzone na obraz Boga (homo est imago Dei), który powołuje do istnienia „z nicości” (ex nihilo) bezpośrednio każdą indywidualną duszę. Według teologów człowiek, jako istota społeczna i religijna, wykazuje potencjał kulturotwórczy, potrzebę życia wspólnotowego oraz poznawczo-wolitywne otwarcie na transcendencje (homo est capax Dei), co ma świadczyć o jego odrębności - przynajmniej częściowej - wobec świata przyrody².

Zarysowana wyżej koncepcja antropologiczna opiera się na wielu założeniach o filozoficznym i biblijnym rodowodzie, które w świetle osiagnięć nauk ewolucyjnych bywają kwestionowane ${ }^{3}$. „Ewolucjonizm zmienił optykę - to nie świat został stworzony dla człowieka, to ludzie ewoluowali tak, by dopasować się do środowiska [...] teoria Karola Darwina - jak twierdzi Steve Stewart-Williams - pokazuje, że jesteśmy jednym $\mathrm{z}$ milionów gatunków, nie mającym żadnych podstaw, by rościć sobie prawo do jakiejkolwiek wyjątkowości i do wyższości”4 ${ }^{4}$. Filozoficzno-teologiczna idea natury ludzkiej ${ }^{5}$, w ramach

2 Więcej na temat chrześcijańskiej koncepcji osoby: W. Granat, Personalizm chrześcijański. Teologia osoby ludzkiej, Poznań 1985; K. T. Wencel, Traktat o człowieku, w: Dogmatyka, t. 5, Warszawa 2007, s. 15-174.

3 Zob. M. Konarzewski, Ewolucja natury ludzkiej, „Archeus” 7 (2006), s. 24.

4 S. Stewart-Williams, Darwin, Bóg $i$ sens życia, tłum. P. J. Szwajcer, Stare Groszki 2014, s. 210.

5 Warto przy tym uściślić, że nauki biologiczne w zasadzie nie operują pojęciem „natury ludzkiej”. Jest to termin o filozoficznym rodowodzie, wskazujący na zbór stałych cech charakterystycznych dla naszego gatunku. Niemniej jednak trzeba zaznaczyć, że sformułowanie to pojawia się często w popularyzatorskich pracach socjobiologów i psychologów ewolucyjnych, którzy wypowiadają się o „naturze ludzkiej” w kontekście sporu o genetyczne i środowiskowe uwarunkowania osobowości. Termin „natura ludzka” odnosi się wówczas do genetycznego wyposażenia człowieka i wyraża zbiór biologicznych uwarunkowań zachowania przedstawicieli gatunku Homo sapiens. Zob. np. E. O. Wilson, O naturze ludzkiej, tłum. B. Szacka, Warszawa 1988; S. Pinker, Tabula rasa. Spory o naturę ludzka, tłum. A. Nowak, Gdańsk 2012. 
której teza o szczególnym miejscu człowieka w przyrodzie jawi się jako fundamentalna, stała się przedmiotem krytyki ze strony wielu współczesnych ewolucjonistów. Nie jest to jednak sytuacja zupełnie nowa. Spór o ewolucyjne pochodzenie naszego gatunku toczy się bowiem przynajmniej od czasu, gdy K. Darwin opublikował prace The Descent of Man w $1871 \mathrm{roku}^{6}$. O ile jednak dzisiejsi biologowie zaakceptowali antropologiczne konsekwencje płynące ze strony nauk ewolucyjnych, o tyle w gronie teologów oraz filozofów chrześcijańskich nadal panuje w tej kwestii rozbieżność opinii ${ }^{7}$.

W niniejszej pracy będę jednak świadomie unikał odniesień do złożonego tła historycznego. Postaram się natomiast podjąć problem chrześcijańskiej idei osoby w kontekstach filozoficznym, teologicznym i w nawiązaniu do niektórych wyników nauk ewolucyjnych o człowieku (a zwłaszcza ich filozoficznych interpretacji) ${ }^{8}$. Szczególnie skupię się na tych stanowiskach, które negują nurt antropocentryczny w filozofii człowieka, to znaczy pogląd, w świetle którego osoba uchodzi za centralny element natury, umiejscowiony w hierarchii bytów „wyżej” od innych zwierząt. Zakładam przy tym, że szereg trudności pojawiajacych się w dyskusjach między nauka a wiarą (w obrębie których mieści się interesujące mnie zagadnienie) zdaje się mieć swoje źródła w uwarunkowaniach filozoficzno-metodologicznych przyrodoznawstwa oraz teologii. W związku z tym podejmę również pytanie o rolę, jaka w dialogu teologii z naukową wizją człowieka może pełnić refleksja filozoficzna, która - z racji, o których powiem w następnym rozdziale - wydaje się być szczególnie predestynowana

6 Na ziemiach polskich spór z darwinizmem toczyli po 1871 roku katoliccy filozofowie, m.in. S. Pawlicki i W. Zaborski. Zob. S. Pawlicki, Studyja nad darwinizmem, Kraków 1875; W. Zaborski, Darwinizm wobec rozumu i nauki, Kraków 1886.

7 Świadectwem tego niech będzie opublikowana niedawno książka (T. Kuczyński, Człowiek - twór przyrody czy coś więcej?, Płock 2015), w której autor - katolicki kapłan z tytułem naukowym - opowiada się za zdecydowaną odrębnością człowieka wobec rzeczywistości biologicznej, podważając przy tym ideę ewolucji biologicznej człowieka.

8 Z racji objętości artykułu będzie to ujęcie ograniczone do wybranych aspektów. Celowo skupiłem się na prezentacji przede wszystkim skrajnie naturalistycznych wersji ewolucjonizmu, by uwydatnić różnice, jakie pojawiają się między tymi stanowiskami a chrześcijańską koncepcją człowieka. 
do podejmowania granicznych zagadnień z zakresu „nauka-religia”. W niniejszej pracy rozważony zostanie także problem sensu ludzkiej egzystencji, wyłaniajacy się w tle dyskusji nad statusem człowieka w przyrodzie i w kontekście polemik nad relacją nauki do metafizyki oraz filozofii zorientowanej podmiotowo ${ }^{9}$.

Przedstawione zagadnienia nie są oczywiście nowe. W obrębie antropologii filozoficznej (a także teologicznej) problematyka ewolucji człowieka bywa jednak wciąż nieco marginalizowana. Jeśli chodzi o chrześcijańskich myślicieli, to znajdują się wśród nich uczeni skłonni modyfikować pewne elementy filozoficzno-teologicznej koncepcji osoby $^{10}$, ograniczają się w tym jednak najczęściej do wykorzystywania zdobyczy nowszej filozofii o profilu humanistycznym ${ }^{11}$, pomijając głębszą analizę osiagnięć z zakresu takich dyscyplin jak antropologia fizyczna czy psychologia empiryczna. Z tego powodu ich ujęcia sprawiać mogą wrażenie jednostronnych i mało przekonujacych dla współczesnego człowieka.

\section{Człowiek jako problem nauki i religii}

Część uczonych uważa dziś, że po 1859 roku wiele filozoficzno-religijnych ilustracji wyrażajacych wyjątkowość człowieka w przyrodzie zostało zdemitologizowanych. Gdy za sprawą ewolucjonizmu opadła kurtyna stawiana mozolnie przez zachodnią tradycję intelektualna,

9 Taką filozofię rozumiem bardzo szeroko, jako racjonalną refleksję nad egzystencją człowieka w kontekście rzeczywistości przyrodniczej i innych ludzkich podmiotów.

10 Należy podkreślić, że przynajmniej od czasów Karla Rahnera i Edwarda Schillebeeckx'a coraz silniej w obrębie teologii reprezentowany jest nurt antropologiczny, w którym katoliccy myśliciele „każdą hipotezę swoich badań dotyczących objawienia stawiają w taki sposób, że wychodzą od immanencji, od człowieka itd., i ten aspekt rzeczywistości objawionej zawsze pozostaje na pierwszym planie, jako szczególnie wyeksponowany” (C. Vagaggini, Teologia. Pluralizm teologiczny, tłum. J. Partyka, Kraków 2005, s. 86).

11 Popularnością cieszą się zwłaszcza takie nurty jak fenomenologia, filozofia spotkania, hermeneutyka czy filozofia egzystencji. Do tych wszystkich kierunków nawiązywał w swojej twórczości m.in. Józef Tischner. Zob. np. S. Szary, Człowiek podmiot dramatu. Antropologiczne aspekty filozofii dramatu Józefa Tischnera, Kęty 2005 . 
dwudziestowiecznym antropologom objawił się nagi potomek małpy: zlepek tkanek i narządów zbudowanych przez geny, które - parafrazując słynną metaforę socjobiologów - trzymają posłuszne zwierzę na smyczy. Z drugiej strony, minione stulecie przyniosło równiė̇ (przynajmniej od czasów P. Teilharda de Chardin) impuls do interpretacji ewolucjonizmu w kontekście religijnym. Rozpowszechnione jest wprawdzie przekonanie, że nie sposób utrzymywać dziś tezy o wyjątkowym miejscu człowieka w przyrodzie i równocześnie w pełni akceptować wszystkich wniosków wypływających z teorii ewolucji ${ }^{12}$. $\mathrm{W}$ praktyce jednak filozoficzne interpretacje ewolucjonizmu moga przybierać rozmaite formy, niekoniecznie ateistyczne. Odpowiedź na pytanie, czy tak zwany chrześcijański ewolucjonizm (albo teizm ewolucyjny) jest do pogodzenia ze współczesną biologia, stanowi przedmiot wielu studiów ${ }^{13}$. Tutaj przyjmiemy, że taka interpretacja jest na gruncie filozoficznym akceptowalna.

W świetle powyższych uwag, spór o rozumienie człowieka w kontekście rozwoju nauk ewolucyjnych można uznać za fragment bardziej fundamentalnego sporu między postawą naukową a postawą religijną ${ }^{14}$. Teza, że wyniki płynące z tych dwóch rodzajów działalności poznawczej sa ze sobą niezgodne, posiada prawdopodobnie nie mniej zwolenników niż stanowisko odmienne, akcentujące możliwość harmonijnego współistnienia teologii i nauki ${ }^{15}$. Niezależnie

12 Tak uważają m.in. Richard Dawkins, Daniel Dennett czy Sam Harris.

13 Spośród nowszych prac polskich autorów wymienić można np.: J. Życiński, Bóg i ewolucja. Podstawowe pytania ewolucjonizmu chrześcijańskiego, Lublin 2002; J. Życiński, Bóg $i$ stworzenie. Zarys teorii ewolucji, Lublin 2011; M. Słomka, Ewolucjonizm chrześcijański. O pochodzeniu człowieka, Lublin 2004.

14 Dzieje relacji między szeroko rozumianą nauką a religią są bardzo złożone, a ich interpretacja trudna, o czym świadczą liczne opracowania. Zob. np. G. Minois, Kościót i nauka. Dzieje pewnego nieporozumienia. Od Augustyna do Galileusza, tłum. A. Szymanowski, Warszawa 1995; G. Minois, Kościót i nauka. Dzieje pewnego nieporozumienia. Od Galileusza do Jana Pawła II, tłum. A. Szymanowski, Warszawa 1996; O. Pedersen, Konflikt czy symbioza? Z dziejów relacji między nauka a teologia, tłum. W. Skoczny, Tarnów 1997.

15 Wśród autorów zakładajacych konflikt między nauką a religią można wymienić np. T. Clements, Nauka kontra religia, tłum. B. Stanosz, Warszawa 2002. Po przeciwnej stronie znajduje się np. A. McGrath, Nauka i religia, tłum. M. Chojnacki, Kraków 2009. 
od sposobu rozstrzygnięcia tego konfliktu, rozwój przyrodoznawstwa prowokuje dziś pytania o wiarygodność religii chrześcijańskiej. Pytania te szczególnie teraz - gdy nauka nierzadko modyfikuje obraz świata w bardzo krótkich odstępach czasu - wymagają ponownego przemyślenia przez teologów.

\subsection{Rola filozofii w sporze między nauką a religią}

Problem wiarygodności chrześcijaństwa jest jednym z kluczowych zagadnień, jakie podejmuje się w ramach dyscypliny teologicznej zwanej teologia fundamentalną. Dziedzina ta, rozwijana jeszcze kilkadziesiąt lat temu jako apologetyka ${ }^{16}$, służy obecnie przede wszystkim „niesieniu rozumnych przesłanek wiary poszukujacym i wspólnocie wierzących"17. Ponieważ uzasadnienie tezy o wiarygodności chrześcijaństwa (a ściślej: prawdziwości doktryny chrześcijańskiej) w oparciu o religijne credo byłoby klasycznym przykładem błędu petitio principi, teologowie zmuszeni są bazować na zdobyczach filozofii i nauk szczegółowych, aby w sposób kompetentny konfrontować doktrynę Kościoła z pytaniami, jakie pod jego adresem płyna ze strony współczesnej kultury ${ }^{18}$. Czy jednak ten postulat jest przez nich realizowany? Czy teologowie są dziś świadomi, przed jakimi wyzwaniami stoją w kontekście rozwoju nauk przyrodniczych - szczególnie w miejscach, gdzie nauki te skłaniają do przyjęcia stanowisk podważających chrześcijańską wizję człowieka?

Odnosi się wrażenie, że na powyższe pytania wciąż brakuje satysfakcjonujących odpowiedzi. Można jednak przyjać, że ewentualny dialog między nauką a religia, o ile miałyby przynieść owoce na gruncie teologii chrześcijańskiej, powinien dokonywać się przede wszystkim za pośrednictwem filozofii. Z tej racji pytaniu o związki

16 Jako samodzielna dyscyplina teologiczna apologetyka narodziła się wraz z powołaniem pierwszej jej katedry w Tybindze, w roku 1819. Warto zaznaczyć jednak, że dociekana teologiczno-fundamentalne i apologetyczne mają swoją „prehistorię”, zwłaszcza w patrystycznej literaturze apologijnej.

17 H. Seweryniak, Teologia fundamentalna, t. 1, Warszawa 2010, s. 125.

18 Jest to wymóg zakładany już w formacji alumnów. Zob. Dekret o formacji kapłańskiej „Optatam Totius”, nr 15. 
między nauką a teologią towarzyszy również inny problem, mianowicie: jakiej filozofii potrzebuje dziś chrześcijaństwo, aby mogło podjąć merytoryczną dyskusję ze współczesną kulturą? Rola szeroko rozumianej refleksji filozoficznej w dialogu między nauką a religia jest o tyle istotna, że:

(1) w naukach kryją się problemy o filozoficznym rodowodzie, które można poddawać analizie przy użyciu narzędzi logicznych i metodologicznych,

(2) nauki sa „uwikłane” w filozofię: w aspekcie ontologicznym (co ujawniać może analiza natury bytu badanego w naukach), epistemologicznym (obrazuje to analiza źródeł i granic poznania otaczającej nas rzeczywistości), metodologicznym (wynik analizy procedur badawczych stosowanych w nauce oraz problem logiki wyjaśniania naukowego); ponadto filozofia pełnić może rolę źródła inspirującego rozwój programów badawczych (mam tu na myśli jej obecność w tak zwanym kontekście odkrycia naukowego) ${ }^{19}$,

(3) teologia bazuje na przesłankach, metodach i pojęciowym instrumentarium filozoficznym; w tym sensie - stanowiąc źródło pomocnicze teologii - okazuje się koniecznym elementem w procesie wyjaśniania podstawowych twierdzeń dogmatycznych ${ }^{20}$, a także wskazań pastoralnych.

Poczynione założenia z jednej strony wskazuja na powiązania między filozofia a nauka, z drugiej zaś - między filozofia a teologią $^{21}$. Zależności te pojawiają się, co istotne, zwłaszcza w kontekście

19 Założenia o istnieniu problemów filozoficznych w naukach oraz uwikłaniu nauk szczegółowych w filozofii są przyjmowane między innymi przez krakowską szkołę filozofii przyrody, uprawianą w kręgu kontynuatorów programu „filozofii w nauce”, zainicjowanej przez Michała Hellera i Józefa Życińskiego (zob. np. M. Heller, Jak możliwa jest „filozofia w nauce”?, „Studia Philosophiae Christianae” 22/1 (1986), s. 7-19; M. Heller, Czy istnieje autentyczna filozofia przyrody?, „Studia Philosophiae Christianae” 23/1 (1987), s. 5-20; M. Heller, J. Życiński, Epistemologiczne aspekty zwiazków filozofii z nauka, w: Filozofować w kontekście nauki, red. M. Heller, A. Michalik, J. Życiński, Kraków 1987, s. 9-15).

20 Zob. Jan Paweł II, Fides et ratio, nr 66.

${ }^{21}$ Dokładne przebadanie zależności między filozofia, teologią a naukami przyrodniczymi w interesujacym mnie tutaj aspekcie wymagałoby niewątpliwie drębnego studium. 
wspólnych problemów nauki i religii, dotyczących między innymi koncepcji człowieka. Sugeruje to, że z korzyścią dla dialogu między nauką a religią byłoby wykorzystanie przez teologów metod takiej filozofii, która z jednej strony byłaby zgodna z doktryną chrześcijańska, a z drugiej niesprzeczna z wynikami nauk i kompetentna do analizy problemów filozoficznych, które się w tych naukach znajduja. Czy jednak wypracowanie takiej metody filozoficznej jest w ogóle osiagalne? ${ }^{22}$

Chrześcijańska antropologia personalistyczna bazuje na optymistycznym przeświadczeniu, iż możliwe jest opracowanie kompleksowej, „całościowej” (albo integralnej, jak wolą niektórzy) koncepcji człowieka, uwzględniającej najistotniejsze elementy natury ludzkiej $^{23}$. Nawet zakładając, że taki ideał wiedzy jest dziś osiagalny, realizacja tego celu u progu XXI wieku byłaby uzależniona nie tylko od wykorzystania metod i pojęciowego zasobu filozofii, ale zwłaszcza od uwzględnienia wyników nauk empirycznych. Niestety, w ramach współczesnej teologii bardzo rzadko rozwijany jest namysł nad wyjaśnieniami proponowanymi przez przyrodoznawstwo ${ }^{24}$. Niewiele

22 Historia filozofii pokazuje, że taką próbą był tomizm - filozofia „bytu jako bytu”, przez kilka stuleci uznawana za ostateczną i najbardziej pożądaną propozycję myślenia w teologii.

${ }_{23}$ Zob. np. G. Barth, Ku całościowej wizji osoby ludzkiej. Metodologiczne założenia personalizmu chrześcijańskiego, „Teologia w Polsce” 2/1 (2008), s. 43-53.

${ }_{24}$ Taki stan rzeczy ma być może swoje historyczne korzenie. W okresie patrystycznym i średniowieczu, gdy filozofia obejmowała równocześnie wiedzę przyrodnicza, problem różnic między postawą naukową a postawą filozoficzną nie występował z pewnością w tak zaostrzonej jak obecnie postaci; metodologiczne rozdzielenie płaszczyzny filozoficznej od płaszczyzny naukowej zaczęło następować dopiero u progu czasów nowożytnych. Antropologiczne koncepcje obecne w patrystyce, a później w okresie scholastycznym, mogły zatem uchodzić za racjonalne, o ile wyrażały aktualny stan wiedzy w ramach danego systemu metafizycznego. Z czasem jednak, wskutek szybszego rozwoju nauk przyrodniczych w okresie nowożytnym, a zwłaszcza w kontekście rozwoju biologii człowieka w XIX wieku, drogi metafizyki i antropologii naukowej zaczęły się rozchodzić. Niemniej idea „całościowej” antropologii była wciąż podejmowana w chrześcijańskiej teologii, najczęściej w oparciu o dane pochodzące z metafizyki i bez znaczącego odniesienia do wiedzy z zakresu antropologii przyrodniczej. Pewien przełom w tej kwestii zaczą następować dopiero po II wojnie światowej i Soborze Watykańskim II, o czym świadczą np. P.G. Fothergill, Chrześcijanie wobec ewolucji, tłum. T. Górski, Warszawa 1966; T. Wojciechowski, Wybrane zagadnienia z filozoficznej antropologii, Kraków 1985. 
wskazuje również na to, aby sytuacja mogła w najbliższym czasie ulec zmianie ${ }^{25}$.

W obrębie teologii i filozofii chrześcijańskiej wciąż mocno zakorzenione jest przekonanie, że poznanie istoty człowieka dokonać się może przede wszystkim drogą „odgórną, tj. poprzez interpretację bytu w ogóle i specyfiki bytu osobowego, wyrażajacego się w jego rozumności oraz wolności. Sprawia to, że problematyka antropologiczna przenosi się przede wszystkim na grunt ontologii; najczęściej zaś jest to ontologia typu tomistycznego, ciesząca się przez wieki dużym poparciem ze strony Kościoła katolickiego ${ }^{26}$. O trudnościach z wykorzystaniem spuścizny św. Tomasza z Akwinu w kontekście rozwoju nauki współczesnej napisano już wiele. Czy dziś ten rodzaj filozofowania jest $\mathrm{w}$ stanie nawiązać owocny dialog z przyrodoznawstwem? Nie miejsce, aby rozstrzygać tutaj ten problem. Trudno jednak zaprzeczyć, że tomizm, zwłaszcza w niektórych odmianach ${ }^{27}$, bywa systemem zamkniętym, tj. filozofią zorganizowaną wyłącznie wokół hermetycznych pojęć, przez co nie uzyskuje potwierdzenia ani zanegowania $\mathrm{w}$ kontakcie $\mathrm{z}$ szeroko rozumianym doświadczeniem: zarówno subiektywnym, podmiotowym (co często sprawia, że chrześcijańska antropologia staje się mało atrakcyjna poznawczo w humanistyce), jak również tym o charakterze naukowym, intersubiektywnie sprawdzalnym.

Niewątpliwie tomizm jest filozofia, która odegrała w dziejach chrześcijaństwa znacząca rolę. Jej konkluzywny charakter przez kilka wieków sprzyjał powiązaniu z religijnym obrazem świata.

${ }^{25} \mathrm{Z}$ przykrością należy odnotować, że obecnie nawet programy studiów teologicznych nie uwzględniaja chociażby podstaw wiedzy matematyczno-przyrodniczej, a ewentualne zagadnienia związane $\mathrm{z}$ naukami szczegółowymi porusza się w ramach jedno- lub, w wyjątkowych przypadkach, dwusemestralnego kursu z filozofii przyrody. Nie dziwi więc, że także w ramach antropologii teologicznej w niewielkim tylko stopniu bierze się pod uwagę wyniki płynące na przykład ze strony współczesnej biologii ewolucyjnej.

26 Znamienne, że jeszcze w 1879 roku papież Leon XIII w encyklice Aeterni Patris uważał tomizm za najdoskonalszy system filozoficzny dla katolika.

${ }^{27}$ W literaturze polskojęzycznej wyróżnia się kilka rodzajów tomizmu: tomizm tradycyjny (zachowawczy), tomizm lowański, tomizm egzystencjalny. Zob. np. K. Mikucki, Tomizm w Polsce po II wojnie światowej, Kraków 2015, s. 16-30. 
Z drugiej strony trudno nie zgodzić się z Tischnerem, który blisko pół wieku temu pisał, iż „niemal wszystkie ogniska zapalne sporów przenikajacych współczesny katolicyzm stoją w bezpośrednim lub pośrednim związku z tomizmem”, zaznaczając równocześnie, że obecny kryzys religijny „nie jest kryzysem chrześcijaństwa, lecz jest to kryzys pewnej historycznej wersji interpretacyjnej chrześcijaństwa"28. Czy teologowie sa jednak w stanie porzucić ten względny obraz religii chrześcijańskiej? A nawet jeśli, to czy potrafią poddać gruntownej modyfikacji język teologii, niezależnie od instrumentarium pojęciowego filozofii tomistycznej? Pytania sa o tyle istotne, ponieważ teologia - zarówno systematyczna, jak i praktyczna - pozostaje w dużej mierze uzależniona od aparatury filozoficznej, bazując na rozumowaniach, w których wnioski wyprowadzane są z przesłanek akceptowalnych głównie w filozofii tomistycznej (na co również zwracał uwagę m.in. wspomniany już Tischner ${ }^{29}$ ).

Podniesione problemy z pewnością nie są nowe, niemniej wciąż powracaja, zwłaszcza w kontekście rozwoju nauk przyrodniczych, które dostarczaja dziś akceptowalnej w środowisku akademickim wiedzy o otaczajacym nas świecie. Wobec problematyki dotyczącej człowieka nasilają się one w sposób szczególny, pokazując, że zagadnienie szeroko rozumianej obecności filozofii w teologii pozostaje aktualne.

\subsection{Metodologia jako miejsce konfrontacji}

Do problematyki związanej z filozofią tomistyczna jeszcze powrócę w kilku miejscach ${ }^{30}$. Tutaj zwrócę tylko uwagę, że metoda tomistyczna

28 J. Tischner, Schyłek chrześcijaństwa tomistycznego, „Znak” 187/1 (1970), s. 1, 14. Można jednak sprzeczać się, czy na pewno określony typ filozofii jest jedynym, głównym powodem „kryzysu w chrześcijaństwie”.

29 Zob. J. Tischner, Schytek chrześcijaństwa tomistycznego, dz. cyt., s. 1, 14.

30 Dodać przy tym należy, że nie oceniam jednoznacznie negatywnie filozofii tomistycznej. Z historycznego punktu widzenia filozofię tę należy wyróżnić, uznając jej zasługi w budowaniu filozoficzno-teologicznej wizji świata w XIII wieku, odzwierciedlającej ówczesny stan wiedzy naukowej. Zob. M. Heller, Z. Liana, J. Mączka, W. Skoczny, Nauki przyrodnicze a teologia: konflikt $i$ wspótistnienie, Tarnów 2001, s. 94-126. 
zakłada pewien typ separacji między epistemologią naukową a epistemologią filozoficzna, nie biorąc pod uwagę, że każda metoda - o ile prowadzi do pogłębienia wiedzy o swoim przedmiocie badań - może okazać się poznawczo pożyteczna (także wówczas, gdy sprzyja prowadzeniu wieloaspektowych badań nad człowiekiem). Obawy przed metodologia nauk empirycznych mogą wyrastać zwłaszcza ze względu na postulowane w obrębie przyrodoznawstwa zasady naturalizmu i redukcjonizmu. Zalecenie, aby każde fizyczne zjawisko czy obiekt tłumaczyć poprzez odwołanie się wyłącznie do stanów fizycznych, a procesy złożone lub odnoszace się do nich teorie sprowadzać do podstawowych zjawisk lub pojęć teoretycznych, bywa niekiedy interpretowane jako wyraz ontologii, w której postuluje się materialistyczny monizm, tzn. tezę o swego rodzaju „wyczerpywalności” rzeczywistości w sferze fizycznej, resp. materialnej ${ }^{31}$. Teza, iż cały świat jest zorganizowany według kilku praw natury, skłania w dodatku niektórych współczesnych naukowców do deprecjonowania znaczenia poznawczego innych dyscyplin niż przyrodnicze, względnie do ich „wchłonięcia” przez przyrodoznawstwo ${ }^{32}$. W tym świetle teologia jawi się zasadniczo jako bezproduktywna, nienaukowa dziedzina dociekań.

Ideał zunifikowanej nauki, postulowany już przez Koło Wiedeńskie, bywa dla wielu filozofów i uczonych równie pociagający, co przekonanie o tym, iz „w naukowej koncepcji świata nieznane są żadne nierozwiązywalne zagadki”, zaś analiza tradycyjnych problemów filozoficznych pozwala zdemaskować je „jako pseudoproblemy, a częściowo przekształcić w zagadnienia empiryczne, poddając tym samym osądowi nauk empirycznych"33. Antropologia chrześcijańska, wraz z koncepcją natury cielesno-duchowej człowieka, zostaje w tym kontekście osądzona jako pseudonauka, nie spełniając kryterium weryfikacji i naruszając zasadę ekonomii myślenia. Co więcej,

${ }^{31}$ Termin „materia” jest pochodzenia filozoficznego, w naukach zastępuje się go np. pojęciem masy czy energii.

32 E. O. Wilson, Konsiliencja. Jedność wiedzy, tłum. J. Mikos, Poznań 2011, s. 1011, 16-17.

${ }^{33}$ Naukowa koncepcja świata. Koło Wiedeńskie, red. H. Hahn, O. Neurath, R. Carnap, tłum. A. Koterski, w: Naukowa koncepcja świata. Koło Wiedeńskie, red. L. Brogowski, Gdańsk 2010, s. 77. 
wypowiedzi teologów nie ratowałoby tutaj także stanowisko K.R. Poppera, który wdał się w polemikę z wiedeńczykami. Z punktu widzenia jego metody hipotetyczno-dedukcyjnej sensowność twierdzeń chociażby o przymiotach duszy ludzkiej (substancjalność, duchowość, jedność, nieśmiertelność) mogłaby zostać podważona, ponieważ nie mogą ich sfalsyfikować dane pochodzące z doświadczenia ${ }^{34}$.

Majac to na uwadze, łatwiej jest być może zrozumieć opór części teologów przed stanowiskami wypracowanymi w obrębie ogólnej metodologii nauk. Opór ten wynikałby bowiem nie tylko z obawy przed naturalizmem i redukcjonizmem przyrodoznawstwa, ale również postulowanymi przez filozofów nauki kryteriami naukowości (przenoszac tym samym interesujące nas zagadnienie do bardziej fundamentalnego sporu o demarkację). Można oczywiście wysunąć twierdzenie, że postulowane przez teoretyków metody naukowe nie wyznaczaja definitywnych i absolutnych kryteriów racjonalnego dyskursu. Można również podnieść tezę, że w samej praktyce badawczej postępowanie uczonych bywa niejednolite, a droga do osiagnięcia wyznaczonego celu naukowego jest niekiedy naznaczona metodologicznym anarchizmem (P. Feyerabend), co mogłoby skłaniać do większego dystansu wobec postulatów formułowanych przez filozofów nauki. Istotny w tym kontekście byłby również argument o uwarunkowaniach społecznych świata naukowego. Ten bowiem, jako twór i część konkretnej kultury, rozwija się nie tylko w sposób zależny od prawideł nadanych przez kolejne odkrycia, ale także w oparciu o sytuację społeczna, warunkującą często określony „styl myślowy" (Ludwik Fleck) czy - jak chciał Thomas Kuhn - powstały wskutek rewolucji intelektualnej ,paradygmat nauki” ${ }^{35}$.

Uwzględnienie tych czynników, obecnych w procesie uprawiania nauki, nie powinno jednak skłaniać do kwestionowania różnic między science a innymi formami aktywności intelektualnej człowieka,

34 Sam Popper wprawdzie nie negował zasadności twierdzeń religijno-metafizycznych, jednak czynił to już - w nawiązaniu do falsyfikacjonizmu - na przykład A. Flew. Zob. A. Flew, Theology and Falsification, w: Reason and Responsibility: Readings in Some Basic Problems of Philosophy, red. J. Feinberg, Belmont 1968, s. 48-49.

${ }_{35}$ Zob. T. Kuhn, Struktura rewolucji naukowych, tłum. H. Ostromęcka, Warszawa 2001. 
takimi jak sztuka czy literatura. Odrzucając wyidealizowany obraz nauki, nie sposób zarazem deprecjonować wyników, jakie osiaga współczesne przyrodoznawstwo, a których wartość jest najczęściej niezależna od kontekstu społeczno-kulturowego ${ }^{36}$. Z tej racji chrześcijańscy teologowie, o ile pragną w sposób rzetelny dostarczać rozumnych przesłanek wiary (zgodnie z wymogiem stawianym $\mathrm{w}$ teologii fundamentalnej), byliby zobowiązani do konfrontowania nauczania Kościoła z wynikami nauk empirycznych. Otwarte pozostaje jednak pytanie, jakimi środkami mogliby się posługiwać w realizacji tego przedsięwzięcia.

Przywołano wcześniej tezę, że konfrontacja taka ma szansę przynajmniej częściowo ziścić się dzięki wykorzystaniu metod i pojęciowej aparatury filozofii, rozumianej tutaj jako swego rodzaju dyscyplina pomostowa, która ze względu na wewnętrzną wieloaspektowość mogłaby wejść w kontakt zarówno z naukami matematyczno-przyrodniczymi, jak i teologią ${ }^{37}$. Podjęcie głębszych studiów nad osiagnięciami przyrodoznawstwa, a także nad filozofią (najlepiej w możliwie najszerszym kontekście, jakie daje zwłaszcza historia filozofii), byłoby z tego względu bardzo pożądane. Przyjmujac, że źródłem poznania teologicznego jest objawienie Boże wyrażone w Biblii i Tradycji ${ }^{38}$, teologowie mogliby równocześnie przystapić do badań nad rolą oraz znaczeniem filozofii szczególnie w nawiązaniu do tego drugiego źró$\mathrm{dła}^{39}$. Zakładając uwikłanie teologii w filozofii, a filozofii w naukach

36 Zwracał na to uwagę m.in. J. Życiński. Zob. np. J. Życiński, Granice racjonalności. Eseje z filozofii nauki, Warszawa 1993, s. 25-45.

${ }_{37} \mathrm{Z}$ racji na zmieniajaccy się naukowy obraz świata, trudno wyobrazić sobie, aby mogła to być filozofia rozumiana jako zamknięty system metafizyczny, jak np. tomizm.

38 Jest to ujęcie specyficzne dla tradycji katolickiej.

39 Wiemy dziś, że proces rozwoju tekstów biblijnych i doktryny chrześcijańskiej (Tradycji) dokonywał się w pewnych kontekstach historyczno-kulturowych, które należy uwzględniać przy badaniu podstaw wiary (fides quae). Dzięki temu można odróżnić istotną z punktu widzenia teologii treść wierzeń od jej względnych komponentów (znane obecnie prace badawcze na tym polu to np. problem niewoli babilońskiej w okresie redakcji Księgi Rodzaju i w związku z tym wpływ kultury mezopotamskiej na poemat o stworzeniu; sytuacja polityczna Żydów za czasów Jezusa a problem mesjanizmu; oddziaływanie myśli neoplatońskiej na dogmatykę i stoickiej na etykę w pierwszych wiekach chrześcijaństwa). Współczesne rozumowania teologiczne również nie są wolne od komponentów pozadoktrynalnych, wspierając się 
(choćby przez zakresowo wspólny obszar tematyczny, nie wspominając o łączącej ich historii), problem relacji nauki do teologii widziałbym jako część sporu dotyczącego sposobu uprawiania filozofii chrześcijańskiej. Czy dziś istnieje taka metoda filozoficzna, która mogłaby bez popadania w sprzeczność pozostać otwarta na religię i zarazem, przy zaakcentowaniu odrębności płaszczyzn, podejmować namysł nad osiagnięciami nauki w aspekcie przedmiotowym (zagadnienia dotyczące bezpośrednio przyrody) i metaprzedmiotowym (zagadnienia dotyczące teorii przyrodniczych)? Pytanie to wydaje się kluczowe między innymi w kontekście problemów, jakie rodzą się na styku antropologii chrześcijańskiej i nauk ewolucyjnych o człowieku.

\section{Człowiek w ujęciu nauk ewolucyjnych}

Wśród teologów krąży żartobliwe powiedzenie, że największą pokusa ich zawodu jest brak wyczulenia na wątpliwości natury poznawczej. Dowolne kwestie sporne w teologii rozstrzygnąc można bowiem albo odwołaniem się do autorytetu Biblii i orzeczeń Kościoła, albo tajemnica wiary, z która - z przyczyn oczywistych - trudno dyskutować. Oczywiście takie postawienie sprawy, w dużym stopniu uproszczone i stereotypowe, stawiać może chrześcijańskich myślicieli w mało komfortowej sytuacji. Z drugiej strony trudno nie odnieść wrażenia, że wraz z postępem wiedzy naukowej powiększa się niekiedy krag teologicznych tajemnic. Historia relacji między nauką a religia zna zresztą wiele takich przykładów ${ }^{40}$. W tym rozdziale przyjrzymy

na przesłankach i przed-założeniach o charakterze filozoficznym, co widoczne jest chociażby w teologii dogmatycznej (np. problem relacji łaski i wolności, zagadnienie Boga w teologii naturalnej, koncepcja Trójcy Świętej), teologii fundamentalnej (argumentacja za wiarygodnością chrześcijaństwa) czy teologii moralnej (koncepcja osoby, actus humanus i jego rozumienie).

${ }_{40}$ Problem nie jest zresztą ograniczony do dyscyplin przyrodniczych. Wiemy dziś, że postępy w biblistyce zmodyfikowały dawne wyobrażenia teologów o powstawaniu poszczególnych ksiag, ich autorstwie, historyczności opisywanych wydarzeń czy sposobie interpretacji danych perykop. Pogłębione w XX wieku badania nad patrystyką pokazały z kolei, że wczesne chrześcijaństwo rozwijało się w ogniu zaciętych 
się konsekwencjom, jakie dla chrześcijańskiej koncepcji człowieka zrodziły wyniki nauk ewolucyjnych.

\subsection{Człowiek - maszyna genowa?}

Warto w tym miejscu przypomnieć, że stanowisko Kościoła katolickiego wobec antropologii bazujacej na teorii ewolucji podlegało na przestrzeni minionego wieku licznym przeobrażeniom. $\mathrm{O}$ ile jeszcze w orzeczeniach Papieskiej Komisji Biblijnej z 1909 roku oddalano wszelkie ewolucjonistyczne wyjaśnienia antropogenezy, o tyle już niespełna pół wieku później, w encyklice Humani Generis (1950) papież Pius XII dopuszczał dyskusję o podchodzeniu ciała ludzkiego z materii istniejącej uprzednio i organicznej, podkreślając przy tym, że badania takie należy prowadzić „, umiarem, powaga, opanowaniem”41. Poligenizm uznany został wówczas za pogląd sprzeczny z nauka katolicka, jako niemożliwy do pogodzenia z dogmatem o grzechu pierworodnym. Kolejny krok w kierunku akceptacji teorii ewolucji nastapił zwłaszcza za pontyfikatu Jana Pawła II. W roku 1996, podczas przesłania do członków Papieskiej Akademii Nauk z okazji sesji pt. „Powstanie i pierwotna ewolucja życia”, polski papież stwierdził, że teoria ewolucji jest czymś więcej niż hipoteza.. Jan Paweł II zwrócił wówczas uwage na problem filozoficznych interpretacji ewolucjonizmu, odrzucając monistyczne poglądy kwestionujące istnienie pierwiastka duchowego w człowieku bądź zakładające, że duch jest wytworem sił materii ożywionej lub jej epifenomenem.

Poczynione kroki w kierunku akceptacji teorii ewolucji nie zmarginalizowały jednak pytań i wątpliwości, jakie przed teologią chrześcijańską stawia ewolucjonizm. Trudności te wyrastają niekiedy w tle dyskusji, jakie toczą się na gruncie biologii ewolucyjnej (np. spór o jednostkę czy - jak woli Ernst Mayr - obiekt doboru naturalnego ${ }^{42}$; prognozy ewolucji naszego gatunku), zwłaszcza zaś stanowią efekt

polemik między różnymi stanowiskami, zaś kształtowanie się doktryny nie było wolne od uwarunkowań politycznych, kulturowych oraz filozoficznych swoich czasów.

${ }^{41}$ Pius XII, Encyklika „Humani Generis”, nr 36.

42 E. Mayr, To jest biologia. Nauka o świecie ożywionym, tłum. J. Szacki, Warszawa 2002, s. 36. 
polemik toczonych wokół filozoficznych interpretacji ewolucjonizmu (np. czy ewolucja przebiega w sposób celowy? ${ }^{43}$. W kontekście filozoficznych analiz nad osiagnięciami antropologii fizycznej pojawia się między innymi pytanie dotyczace miejsca i roli przedstawicieli Homo sapiens w świecie ożywionym. Czy człowiek jest w przyrodzie bytem wyjątkowym, to znaczy jakościowo różnym od innych organizmów (ze względu na wpisane w jego naturę atrybuty) i niesprowadzalnym, przynajmniej pod pewnymi względami, do sfery biologicznej?

Wielu uczonych odpowiada na to pytanie przeczacco. Jak pisał Jacques Monod, „nauka rujnuje wszystkie koncepcje ontogenezy mitycznej lub filozoficznej, na których tradycja animistyczna od Indian australijskich do materialistycznych dialektyków opierała wartości, moralność, obowiązki, prawa i zakazy. Jeżeli człowiek zgodzi się przyjąć ten przekaz w całym jego znaczeniu, to musi się nareszcie zbudzić z tysiacletniego snu, aby odkryć swoją zasadnicza obcość. Teraz już wie, że tak jak Cygan znajduje się na marginesie Wszechświata, w którym wypadło mu żyć. Wszechświata głuchego na jego pieśń, obojętnego na jego nadzieje, na jego cierpienia, na jego zbrodnie"44. Konsekwencje wypływające ze słów francuskiego biochemika mogą wydać się pesymistyczne. Człowiek nie jest już tutaj ukoronowaniem stworzenia, lecz jawi się jako tymczasowy, niewiele znaczacy byt egzystujacy wyłącznie według zasad stanowionych przez naturę. Przedstawiciel Homo sapiens to jeden z gatunków zwierzęcych, podlegajacy takim samym prawom, jakim podlegają inne organizmy, w tym procesowi ewolucji rozumianej jako gra przypadku (mutacje) i konieczności (dobór naturalny). Zamieszkuje niewielka planetę okrążającą zwykłą gwiazdę, nie wyróżniającą się spośród innych gwiazd Drogi Mlecznej, która jest z kolei jedną z kilkuset miliardów galaktyk widzialnego uniwersum. Będąc częścią świata

43 Dodać należy, że przedmiotem sporu są wciąż nawet tak fundamentalne kwestie, jak definicja życia czy zagadnienie powstania życia i wczesnej ewolucji biologicznej. Zob. np. K. Chodasewicz, Definiować czy nie? Wspótczesne kontrowersje na temat potrzeby i sposobu definiowania życia, „Kosmos” 63/4 (2014), s. 501-516; J. Weiner, Hipotezy o powstaniu i wczesnej ewolucji życia, „Kosmos” 58/3-4 (2009), s. 501-528.

${ }_{4}$ J. Monod, Przypadek i konieczność. Esej o filozofii biologii współczesnej, tłum. J. Bukowski, Warszawa 1979, s. 108-109. 
ożywionego wywodzi się od wspólnego dla wszystkich organizmów przodka, a scenerię dziejów życia, po których kroczy, ukształtowały nie tylko procesy ewolucyjne, ale także inne, nieprzewidywalne i przypadkowe zjawiska zewnętrzne (jak choćby uderzenie w Ziemię asteroidy 65 milionów lat temu). Dysponuje kodem genetycznym, którego cechy biologiczne sa takie same jak u prawie wszystkich pozostałych form żywych, łącznie z bakteriami i wirusami, zaś niemal w stu procentach jest genetycznie identyczny z szympansem.

Czy w związku z powyższym teza o naszym wyjątkowym miejscu w przyrodzie zachowuje jeszcze ważność? A może nie pozostało nic innego, jak uznać, iż człowiek jest tylko niewiele znaczącym dziełem przypadku, osamotnioną istotą w ,wielkim, trupim dole wszechświata", jak poetycko ują to Jean Paul ${ }^{45}$ ? Niewatpliwie takie ujęcie wyrażałoby jedną z możliwych filozofii człowieka. Co ciekawe, podobna wizja mogłaby współgrać z wieloma innymi koncepcjami wyrosłymi na gruncie współczesnego ewolucjonizmu, np. z propozycjami brytyjskiego uczonego i popularyzatora nauki, Richarda Dawkinsa.

Wśród idei zawartych na kartach jego pierwszej książki, czyli „Samolubnego genu”, zwłaszcza dwie tezy okazały się sporym wyzwaniem rzuconym w stronę tradycyjnej antropologii filozoficznej: mianowicie teza o genach (nie zaś osobnikach czy populacjach) jako obiektach doboru naturalnego, a także teza o organizmach jako tymczasowych, fizycznych „powłokach” dla genów. „Jesteśmy oto maszynami przetrwania - zaprogramowanymi zawczasu robotami, których zadaniem jest ochranianie samolubnych cząsteczek, zwanych genami. Prawda ta wciąż naprawa mnie zdumieniem i chyba nigdy nie przestanie, choć znana mi jest od lat" ${ }^{46}$. Te metaforyczne sformułowania wydaja się niemal streszczać zasadnicze przesłanie całej książki oraz późniejszych poglądów brytyjskiego uczonego. Przesłanie to nie płynie tylko i wyłącznie w stronę biologów. Oto Dawkins uważa, że człowiek - podobnie jak inne organizmy - jest niczym więcej, jak tylko krótkotrwałą (w perspektywie osobniczej

45 J. Paul, Mowa wypowiedziana przez umartego Chrystusa ze szczytu kosmicznego gmachu o tym, że nie ma Boga, „Kronos” 16/1 (2011), s. 73.

46 R. Dawkins, Samolubny gen, tłum. M. Skoneczny, Warszawa 1996, s. 7. 
i gatunkowej) „maszyna przetrwania” (survival machines) dla potencjalnie nieśmiertelnych replikatorów, jakimi sa geny, decydujące o budowie poszczególnych indywiduów i strategii ich zachowania.

Chociaż hipoteza samolubnego genu wzbudzała przed laty ożywione dyskusje w kręgach niektórych uczonych ${ }^{47}$, to jej zależność m.in. od rozwoju genetyki populacyjnej, teorii doboru krewniaczego czy koncepcji strategii ewolucyjnie stabilnych była dla biologów lat siedemdziesiątych - w tym dla samego Dawkinsa - oczywista ${ }^{48}$. Dziś koncepcja człowieka jako bytu zanurzonego w naturze, dla której istoty ludzkie sa tylko jednym z możliwych środków do realizacji celu, jakim jest powielanie kopii genów, stanowi wyzwanie zwłaszcza dla antropologów chrześcijańskich ${ }^{49}$. Mimo że brytyjski uczony rozszerza swoje ujęcie człowieka jako „maszyny przetrwania” o tezę dotycząca specyficznego dla naszego gatunku przekazu kulturowego (memetycznego), to w gruncie rzeczy traktuje istoty ludzkie jako osobniki wyłącznie biologiczne - wraz ze wszystkimi

47 Rzecz znamienna, że z perspektywy czasu Samolubny gen doczekał się chyba większej ilości komentarzy ze strony humanistów i przedstawicieli nauk społecznych, niż rodzimych sciences, z którymi Dawkins pozostaje przecież związany zawodowo. Dla tych pierwszych niektóre poglądy zawarte na kartach tej ksiązki mogły w pierwszym odruchu okazać się wręcz rewolucyjne (podobnie zresztą było, gdy rok wcześniej na rynku wydawniczym pojawiła się Socjobiologia E. O. Wilsona). Na sukces Samolubnego genu mógł wpłynąć także fakt, iż główne tezy tej książki zostały przekazane w przystępnym języku, obfitującym w działające na wyobraźnię zabiegi metaforyczne, a przy tym ograniczonym do minimum w ilość terminów technicznych i subtelnych zawiłości, pełniących przecież tak istotną rolę w „rozpracowywaniu" problemów badawczych dyscyplin przyrodniczych, nie bez powodu określanych niekiedy szczegółowymi. Okazało się to siłą Samolubnego genu, a zarazem słabościa, powodując wiele niejasności i sporów interpretacyjnych. Terra incognita biologii ewolucyjnej zaczęła pociagać niespecjalistów, zauroczonych jej możliwościami w zakresie wyjaśniania zjawisk spowitych dotychczas nimbem tajemnicy. Inna sprawa, iż w odbiorze pierwszych recenzentów, zwłaszcza z kręgu naukowego, książka zasadniczo nie była odbierana jako kontrowersyjna, o czym Dawkins wspomina w swojej autobiografii (R. Dawkins, Apetyt na cuda. Przepis na uczonego, tłum. P. J. Szwajcer, Warszawa-Stare Groszki 2016, s. 235).

48 R. Dawkins, Samolubny gen, dz. cyt., s. 13; R. Dawkins, Apetyt na cuda..., dz. cyt. s. 222-228.

49 Świadczą o tym polemiki, jakie toczą z Dawkinsem niektórzy filozofowie na gruncie polskim np. A. Marek-Bieniasz, Richarda Dawkinsa geocentryczna interpretacja ewolucji i jej zasadność. Analiza krytyczna, Częstochowa 2008, s. 60-85. 
konsekwencjami płynącymi z przyjęcia takiego stanowiska, które stoją w opozycji do ujęć proponowanych w obrębie teologii i teologicznej metafizyce, przyjmujacych, że człowiek łączy w swej naturze świat ducha ze światem materii.

\subsection{Człowiek - wiązka neuronów?}

Wobec stanowisk zbliżających się do koncepcji Dawkinsa niektórzy filozofowie oraz teologowie podnoszą głos sprzeciwu, nie podzielając tezy o rozumieniu człowieka wyłącznie przez pryzmat posiadanego przezeń genomu. O ile jeszcze akceptowalne jest ewolucyjne pochodzenie ciała ludzkiego, to rozwija się równocześnie refleksję nad własnościami emergentnymi, takimi jak wrażliwość moralna czy wyższe funkcje intelektualne, które miałyby być nieredukowalne do podłoża materialnego (mózgu), co mogłoby równocześnie stanowić podstawę dla filozoficznej hipotezy o istnieniu duchowej sfery w człowieku. Koncepcja emergentnej ewolucji cieszy się obecnie dużym poparciem ze strony chrześcijańskich uczonych, dając im możliwość zbudowania koncepcji antropologicznej bliższej ujęciom chrześcijańskim i wizji naukowej, co pokazują na przykład prace Józefa Życińskiego ${ }^{50}$.

Z drugiej strony w naukach ewolucyjnych dostarcza się dziś hipotez wyjaśniających tak złożone fenomeny, jak tożsamość, samoświadomość, zdolność do refleksji, wrażliwość estetyczna, postępowanie moralne czy wierzenia religijne, bez odwoływania się do filozoficznej koncepcji emergentyzmu. Ważną rolę w tym względzie pełni zwłaszcza psychologia ewolucyjna. W ramach tego podejścia zwraca się uwagę na rolę adaptacji psychologicznych, wpływajacych na behawior przedstawicieli naszego gatunku. Paradygmat ewolucyjny stoi tutaj w opozycji do tych wszystkich nurtów filozofii i psychologii, w których przyjmuje się koncepcję umysłu jako tabula rasa (tzn. zakłada się, iż człowiek nie posiada określonej natury, a jedynie zdolność do uczenia się wskutek oddziaływania czynników zewnętrznych, np. w procesie socjalizacji). Psychologowie ewolucyjni przekonuja,

50 J. Życiński, Wszechświat emergentny. Bóg w ewolucji przyrody, Lublin 2009, s. 73-111. 
że jesteśmy - jako gatunek - wyposażeni w genetyczne dziedzictwo, które stanowi niezbywalny rdzeń naszej natury ${ }^{51}$.

W świetle niektórych koncepcji ewolucyjnych ludzki umysł - rozumiany niekiedy tylko jako suma skończonej liczby reakcji chemicznych i elektrycznych w mózgu (eliminacjonizm ${ }^{52}$ ) - realizuje swoje czynności wyłącznie w celu rozwiązywania problemów adaptacyjnych, z jakimi mierzyli się nasi przodkowie. Według socjobiologów i psychologów ewolucyjnych mózg ewoluował, aby umożliwić przetrwanie i powielenie genów, nie zaś w celach czysto poznawczych, estetycznych czy religijnych ${ }^{53}$. W świetle ewolucyjnej epistemologii proces poznawania jest więc efektem przystosowania do środowiska życiowego, w którym funkcjonował nasz gatunek; z tego względu struktury poznawcze Homo sapiens są dopasowane do otoczenia tylko w takim zakresie, w jakim służyło to przeżyciu naszych przodków.

Paradygmat ewolucyjny proponuje również wyjaśnienia dla wielu innych zagadnień o filozoficznym rodowodzie, jak np. ludzka świadomość (traktując ją często jako uboczną właściwość aktywności elektrycznej mózgu), wolność (w świetle badań z zakresu genetyki, psychologii ewolucyjnej i neurobiologii przyjmuje się tutaj zróżnicowane stanowiska filozoficzne, m.in. determinizm, kompatybilizm ${ }^{54}$ ) czy moralność (rozumiana jako rezultat naturalnej predyspozycji do zachowań altruistycznych, w formie skodyfikowanej traktowanej niekiedy tylko jako „zasłona” dla naszych egoistycznych popędów ${ }^{55}$ ), której źródeł upatruje się zwłaszcza w sferze emocjonalnej

51 Zob. D. Buss, Psychologia ewolucyjna, tłum. M. Orski, Gdańsk 2001, s. 70-79; B. Pawłowski, D. Danel, Psychologia ewolucyjna - nauka o adaptacjach i ewolucyjnej inercji ludzkiego umystu, „Kosmos” 58/3-4 (2009), s. 574-576.

52 Skrajna postać tej koncepcji widać zwłaszcza w: F. Crick, Zdumiewajaca hipoteza, czyli nauka w poszukiwaniu duszy, tłum. B. Chacińska-Abrahamowicz, M. Abrahamowicz, Warszawa 1997, s. 17; A. Damasio, Bład Kartezjusza, tłum. M. Karpiński, Poznań 1999, s. 141.

${ }_{53}$ Zob. np. E. O. Wilson, O naturze..., dz. cyt. s. 28.

${ }_{54}$ Zob. np. J. Bremer, Czy wolna wola jest wolna? Kompatybilizm na tle badań interdyscyplinarnych, Kraków 2013.

55 Zob. np. R. Wright, Moralne zwierze. Dlaczego jesteśmy tacy, a nie inni. Psychologia ewolucyjna a życie codzienne, tłum. H. Jankowska, Warszawa 2003. 
człowieka ${ }^{56}$. Warto przy tym podkreślić, że w obrębie nauk ewolucyjnych trudno znaleźć powszechnie akceptowaną teorię umysłu, świadomości, wolnej woli czy moralności, niemniej za punkt wyjścia przyjmuje się, że procesy psychiczne są przede wszystkim adaptacjami wytworzonymi wskutek działania doboru naturalnego i płciowego w okresie plejstocenu. Sfera psychiczna wraz ze wszystkimi swoimi fenomenami okazuje się niczym więcej, jak wytworem konkretnej historii, sumą następujacych po sobie wydarzeń, które ją zrodziły, nie zaś efektem ingerującego w tę historię Boga, obdarzajaccego człowieka nowymi własnościami, nieredukowalnymi do stanów wcześniejszych.

Antropologia chrześcijańska, bazująca na określonym rozumieniu takich zjawisk jak wolność, moralność czy świadomość, staje tutaj przed poważnymi wyzwaniami, uwidaczniającymi się także w inspirowanej religijnie etyce czy filozofii społecznej. Naturalistyczne wersje ewolucjonizmu podważają właściwie większość fundamentalnych założeń obecnych w chrześcijańskiej koncepcji osoby, takich jak teza o istnieniu duchowego pierwiastka w człowieku czy wolnej woli jako władzy dążącej ku dobru poznawanemu przez rozum. Również idea homo est capax Dei może jawić się ewolucjonistom jako watpliwa, zwłaszcza w kontekście osiagnięć religioznawstwa kognitywnego, w obrębie którego proponuje się hipotezy dotyczące genezy wierzeń religijnych. Wielu badaczy tego nurtu wywodzi religię wyłącznie ze zjawisk naturalnych ${ }^{57}$, przeczac stanowisku o celowo skonstruowanych własnościach osoby, której dążeniom religijnym ma odpowiadać istnienie transcendentnej rzeczywistości ${ }^{58}$. Niektórzy, jak David Sloan Wilson przyjmuja, że religijne wierzenia są wynikiem

${ }^{56}$ W związku z tym uważa się niekiedy, iż właściwie nie istnieje coś takiego, jak obiektywna etyka, kategorie dobra i zła są bowiem tylko przejawami subiektywnych preferencji i nie odpowiada im niezależna od podmiotu rzeczywistość, zaś ludzkie zachowania można ewentualnie rozpatrywać tylko w kategoriach korzyści płynących z przeżycia i reprodukcji. Rozumując w ten sposób, w kontekście ewolucyjnym kategorie dobra i zła nie występuja, istnieją bowiem tylko intuicyjne reakcje i zachowania człowieka, które same w sobie nie są ani dobre, ani złe w sensie etycznym, lecz najwyżej korzystne ewolucyjnie.

${ }_{57}$ Zob. np. D. Dennett, Odczarowanie. Religia jako zjawisko naturalne, tłum. B. Stanosz, Warszawa 2008.

58 Zob. M. Rusecki, Istota i geneza religii, Lublin-Sandomierz 1997, s. 203-204. 
biologicznego przystosowania ${ }^{59}$, inni natomiast - że sa produktem ubocznym różnych adaptacji, same w sobie nie przedstawiając ewolucyjnej wartości dla przetrwania ${ }^{60}$. To, co zwykle określane jest mianem religii, powstawać ma wyłącznie na bazie powiązanych ze soba zwyczajnych procesów poznawczych, zachodzących w naszych mózgach $^{61}$. Przykładowo, według M. Gazzanigi religie wykształciły się, ponieważ stanowiły racjonalizację dla ewolucyjnie wbudowanych w nasz umysł zasad moralnych ${ }^{62}$, a także dlatego, iż sprzyjały kształtowaniu spójnego obrazu otaczającej nas rzeczywistości ${ }^{63}$.

W tym świetle prastare pytanie o człowieka i jego miejsce w świecie stawia się dziśs z pewną nieśmiałością. Czy jesteśmy maszynami genowo-memowymi? A może tylko wiązkami neuronów? Trudno byłoby odpowiedzieć na to pytanie abstrahując od szerokiego kontekstu filozoficznego i naukowego. Oczywistością jest, że na gruncie antropologii przyrodniczej przeczy się koncepcji stałości gatunków, przyjmując anatomiczne pochodzenie współczesnego człowieka od wcześniejszych przedstawicieli rodzaju Homo. Z tym twierdzeniem zasadniczo zgadza się już wielu teologów, stanowisko przyrodników zyskuje zaś zaufanie również w kontekście oficjalnego nauczania Kościoła katolickiego. W naturalistycznych wersjach ewolucjonizmu idzie się jednak dalej, podważając teologiczną tezę o przysługującej człowiekowi godności - nie sposób bowiem wskazać na różnice jakościowe między naszym gatunkiem a innymi organizmami zwierzęcym, zaś kryteria wyjątkowego statusu człowieka w przyrodzie (np. wyższe funkcje intelektualne), stawiane przez antropologów chrześcijańskich, bywają uznane za arbitralne. W tym punkcie pojawiają się już znaczące rozbieżności między ujęciami zainspirowanej nauką filozofii naturalistycznej a ujęciami teologii.

59 Zob. D. S. Wilson, Darwin's Cathedral: Evolution, Religion, and the Nature of Society, Chicago 2002.

60 Zob. S. Atran, Ewolucyjny krajobraz religii, przeł. M. Kolan. Kraków 2013.

61 Zob. np. P. Boyer, I człowiek stworzył bogów... Jak powstała religia?, tłum. K. Szeżyńska-Maćkowiak, Poznań 2001.

${ }_{62}$ M. Gazzaniga, The Ethical Brain: The Science of Our Moral Dilemmas, New York-Washington 2005, s.145-155.

63 M. Gazzaniga, The Social Brain: Discovering the Networks of The Mind, New York 1985, s. 180. 
Według wielu ewolucjonistów w naturę człowieka nie jest wpisany pozabiologiczny cel. Istoty ludzkie istnieja, ponieważ doprowadziło do tego działanie doboru naturalnego (który - jak twierdzi R. Dawkins - jest co najwyżej „ślepym zegarmistrzem”" ${ }^{64}$ ), a nasza egzystencja ma z tego punktu widzenia wartość nie większą i nie mniejsza, niż życie prostych organizmów prokariotycznych. Jesteśmy tylko powłokami dla genów-replikatorów, a tak złożone fenomeny jak kultura, moralność czy wierzenia religijne maja tylko ewolucyjne, tzn. w pełni naturalne pochodzenie. Codzienne dylematy oraz wybory nie powinny być w związku z tym rozpatrywane jako przejawy funkcjonowania wolnej woli i sumienia, o tych bowiem można powiedzieć najwyżej, że są użytecznymi iluzjami. Egzystujemy po to, aby przeżyć i odnieść sukces reprodukcyjny, wykorzystując do realizacji tego celu najróżniejsze - pozornie z tym niepowiązane - wzorce zachowań, których źródła tkwią, czy tego chcemy, czy nie, najczęściej $\mathrm{w}$ sferze intuicyjnej, emocjonalnej ${ }^{65}$, co przeczyłoby powszechnie podzielanemu przekonaniu, iż człowiek to wprawdzie animal, ale jednak rationale. Kierujac się mniej lub bardziej złożonymi mechanizmami psychologicznymi, tak ochoczo uskutecznianymi dzięki bogatej historii ewolucyjnej naszych przodków, zwiększamy bowiem własne szanse na przeżycie.

Koncepcja człowieka, wyłaniająca się z niektórych ujęć ewolucyjnych, w sposób zdecydowany podważa teologiczną wizję osoby. Z drugiej strony trzeba przyznać, że filozofowie chrześcijańscy bywaja skłonni interpretować zjawisko ewolucji w kontekście religijnym, łącząc wizję antropologii teologicznej z osiagnięciami z zakresu nauk ewolucyjnych o człowieku. Świadczy to niewątpliwie o dużym zróżnicowaniu, jakie panuje w obrębie refleksji antropologicznej, a zarazem o olbrzymim potencjale interpretacyjnym, tkwiącym w ewolucjonizmie. Niezależnie od sposobu rozwiązania sporu można zauważyć, że podejmowane dyskusje i polemiki nie mają ani charakteru stricte

${ }_{64}$ R. Dawkins, Ślepy zegarmistrz, czyli jak ewolucja dowodzi, że świat nie zostat zaplanowany, tłum. A. Hoffman, Warszawa 1994, s. 47.

65 Zob. np. D. Kahneman, Pułapki myślenia. O myśleniu szybkim i wolnym, tłum. P. Szymczak, Poznań 2011. 
naukowego (bo nie opierają się na zasadach metodologicznych stosowanych w naukach empirycznych), ani także wyłącznie teologicznego (gdyż nie bazują w pierwszej kolejności na danych pochodzących z objawienia), lecz filozoficzny, czyli taki, który umożliwia wyznaczenie i przeanalizowanie wspólnego zakresu pytań stawianych przez naukę oraz religię.

\section{Antropologia wobec problemu sensu}

Podzielane przez wielu ewolucjonistów założenia naturalistyczne w połaczeniu z postulatem redukcji zakresu istnienia do świata przyrody prowokują na gruncie filozofii człowieka szereg interesujących polemik. Dla antropologów chrześcijańskich założenia te stanowią dodatkowe wyzwanie, ponieważ przyjęcie ich skłaniać może niektórych uczonych do odrzucenia tezy głoszącej związek między inteligibilnością bytu człowieka i jego - tzn. bytu ludzkiego - sensem.

\subsection{Sukces nauk a kryzys sensu}

Michał Heller uważa, że „pytania o sens człowieka i sens Wszechświata są ze sobą ściśle powiązane”. Jeśli bowiem „Wszechświat ma sens, to sens ten prawdopodobnie obejmuje także człowieka, ponieważ człowiek jest częścia - więcej, elementem struktury - Wszechświata"66. W tym kontekście filozofia, bazując na wynikach przyrodoznawstwa, mogłaby podjąć metafizyczny namysł nad pytaniem o sens rzeczywistości (ujmowanym w różnych jej aspektach), powracając przy tym do dawnego pytania Gottfrieda Wilhelma Leibniza: Dlaczego istnieje raczej coś niż nic?

Zawężając problem do antropologii, w koncepcjach chrześcijańskich zagadnienie sensu jest rozpatrywane pozytywnie i przyjmowane jako teza wyjściowa także dla teologii praktycznej. Tymczasem wielu ewolucjonistów uważa, że obszar sensowności kończy się tam,

66 M. Heller, Sens życia i sens Wszechświata. Studia z teologii współczesnej, Tarnów 2002,.s 168 . 
gdzie pojawiają się granice empirii, zaś przekonanie o istnieniu jakiegoś obiektywnego sensu ludzkiej egzystencji traktuje się co najwyżej za przejaw osobistych preferencji, tudzież myślenia życzeniowego. Problem jest jak widać złożony, niemniej jego zakorzenienie w filozofii świadczyłoby po raz kolejny na korzyść właśnie tego rodzaju refleksji w podejmowaniu i rozwiązywaniu wspólnych zagadnień, wyłaniających się na styku nauki i religii.

Współczesny filozof Ray Brassier jest zdania, iż wskutek rozwoju nauk nowożytnych uzyskaliśmy taką wizję świata, w której postulowanie głębszego sensu rzeczywistości wydaje się pozbawione racji. Według tego myśliciela w naukowym obrazie świata „zrozumiałość zostaje oderwana od sensu: konceptualna racjonalność nowożytnej nauki rezygnuje ze struktur narracyjnych, które nadal dominuja w teologii i teologicznej metafizyce. Oznacza to decydujący krok naprzód w powolnym procesie stopniowego uwalniania się ludzkiej racjonalności od mitologii, która polega zasadniczo na interpretowaniu rzeczywistości przez pewną narrację. Świat nie posiada autora i nie istnieje żadna opowieść wpisana w strukturę rzeczywistości”67.

Brassier odrzuca przy tym projekty egzystencjalistów, według których ludzka świadomość może niejako „oddolnie” implementować sens w pozbawionym tego sensu świecie (Jean-Paul Sartre). Takie rozwiązanie wydaje mu się mało wiarygodne, ponieważ w kategoriach nauk przyrodniczych prowadzi się juz badania, w efekcie których „sensy generowane przez świadomość będą mogły być zrozumiane i wyjaśnione jako produkty bezcelowych, choć doskonale zrozumiałych procesów o charakterze zarazem neurobiologicznym i socjohistorycznym"68. Propozycja brytyjskiego filozofa stawia w związku z tym przed licznymi trudnościami także teologów. Nie rezygnując bowiem $\mathrm{z}$ kategorii prawdy - jak czynią to chociażby postmoderniści - Brassier odrzuca próby wikłania jej w określonym systemie metafizyki, negując przy tym wartość poznawczą wypowiedzi

${ }^{67}$ Jestem nihilista, bo wcia $\dot{z}$ wierze $w$ prawdę. $Z$ Rayem Brassierem rozmawia Marcin Rychter, „Kronos” 16/1 (2011), s. 183.

68 Jestem nihilista, bo wcią̇ wierzę $w$ prawdę. $Z$ Rayem Brassierem rozmawia Marcin Rychter, dz. cyt., s. 183. 
formułowanych w ramach tzw. „wielkich narracji”. W tym kontekście chrześcijańska wizja człowieka, bazująca na bogatych odniesieniach metafizycznych (w obrębie których wiedzę o człowieku łączono z przekonaniem o poza-empirycznych własnościach osoby), nie mogłaby znaleźć sojusznika nawet przy większym otwarciu się na wyniki nauk ewolucyjnych i modyfikacji lub zmianie systemu metafizycznego na inny ${ }^{69}$. Tym samym wypowiedzi teologii zostałyby uznane za pozbawione wartości poznawczej.

\subsection{Rola filozofii podmiotu $\mathrm{w}$ pytaniu o sens}

W odniesieniu do poruszanej problematyki pojawia się także pytanie o relacje, jakie zachodzą między filozofią uprawiana w kontekście naukowym a filozofią o profilu humanistycznym, w której kwestia sensu jawi się przecież jako jedna z kluczowych. Wydaje się, że nie jest dobrym rozwiązaniem radykalna separacja tych dwóch ujęć. Kiedy nauki ewolucyjne sugerują określoną wizję człowieka, ich oddziaływanie sięga zwykle daleko poza nurt badań z zakresu dyscyplin takich jak filozofia przyrody, filozofia nauki czy kognitywistyka. Ta uwaga mogłaby zatem skłaniać teologów do podjęcia wysiłków poszukiwania takiej metody filozoficznej, która nie tylko pozostawałby $\mathrm{w}$ zgodzie $\mathrm{z}$ osiagnięciami nauki, ale również nawiązywałaby do pytań egzystencjalnych konkretnego człowieka, rozumianego na przykład - nawiązując do propozycji Tischnera - jako „istota dramatyczna”, żyjącego na określonej „scenie” dramatu (świat

69 Nie wydaje mi się, aby w kontekście tej trudności rozwiązaniem była propozycja Stephena Jay'a Goulda, czyli NOMA (Non-Overlapping Magisteria). Koncepcja ta sugeruje zniesienie sprzeczności między twierdzeniami nauki a religii przez przyjęcie tezy o istnieniu dwóch rozłącznych obszarów dociekań. Zakłada się przy tym milcząco, że pytania o charakterze metafizycznym (teologicznym) są pytaniami poznawczo sensownymi (podczas gdy wartość takich pytań należałoby wpierw uzasadnić), sugerując równocześnie religijny fideizm - w ujęciu NOMA istnieje bowiem radykalny rozdźwięk między pytaniami nauki a pytaniami teologii, tak jakby domeną człowieka religijnego była wyłącznie wiara, która nie jest oparta na rzetelnych przekonaniach dotyczących świata i jego Stwórcy, uobecniającego się w stworzeniu (jak głosi teologiczna protologia). 
badany przez nauki) w sieci relacji międzyosobowych (Ja-Ty, Ja-Inny) ${ }^{70}$. Tak pojmowana filozofia być może posłużyłaby antropologicznie zorientowanej teologii, dostarczajac jej przesłanek do dyskusji z przedstawicielami szeroko rozumianych nauk humanistycznych i przyrodniczych w kontekście pytań o naturę człowieka.

Problemy i trudności, jakie pojawiają się wokół dyskusji dotyczących chrześcijańskiej i ewolucyjnej koncepcji człowieka, mają swoje odzwierciedlenie w filozofii zorientowanej humanistycznie. Pytań o istotę, pochodzenie i przeznaczenie konkretnej osoby nie sposób zawęzić tylko do sporów pojawiających się między teologią a nauka. Przyjmując konsekwencje wypływające ze stanowiska Brassiera, należałoby przyjacć, że w świetle osiagnięć współczesnej nauki człowiek został definitywnie obdarty z narracji metafizycznej, w która "wplątało" go między innymi chrześcijaństwo ${ }^{71}$. Podobne stanowisko, w którym pytanie o sens ludzkiej egzystencji jawić się może jako pozbawione istotnych racji, bywa także podzielane przez niektórych przedstawicieli humanistycznej filozofii, zorientowanej podmiotowo.

Pesymistyczną wizję człowieka kreślił przed kilkudziesięciu laty np. Jean Améry, gdy powracajac do wspomnień z Auschwitz pisał w przejmujący sposób o doświadczeniu bycia torturowanym, które - wbrew zapewnieniom innych ocalałych więźniów, jak Viktor Emil Frank $1^{72}$ - uniemożliwia odzyskanie egzystencjalnego zaufania do świata i drugiego człowieka ${ }^{73}$. W kontekście takich świadectw problem sensu ludzkiego życia nabiera szczególnej wagi; zwłaszcza, gdy jego zwieńczeniem staje się przecząca odpowiedź na pytania: „Czy musi się żyć? Czy musi się istnieć tylko dlatego, że raz się zaist-

70 Zob. J. Tischner, Filozofia dramatu, Kraków 2006.

71 Sens dziejów postulowali również tacy filozofowie jak Immanuel Kant, Georg Hegel czy Karol Marks.

${ }^{72}$ V.E. Frankl, Człowiek w poszukiwaniu sensu, tłum. A. Wolnicka, Warszawa 2009 .

73 „Torturowany nie przestaje się dziwić, że wszystko to, co w zależności od naszych upodobań możemy nazywać duszą, swoim umysłem, świadomością czy tożsamościa, przestaje istnieć, kiedy z chrzęstem i trzaskiem wyłamują się stawy barkowe [...] Kto doznał tortur, nie może się już zadomowić w świecie” (J. Améry, Poza wina i karq. Próby przełamania podjęte przez złamanego, tłum. R. Turczyn, Kraków 2007, s. 100). 
niało?"74, potwierdzona samobójczym aktem. Pozbawioną religijnych odniesień, a przy tym bardzo sugestywną antropologię podzielał również Emil Cioran. Według rumuńskiego myśliciela człowiek to anormalne zwierzę, przykład antynatury, byt - jak to ują - „pod względem psychicznym bardziej pokraczny niż dinozaur pod względem fizycznym"75. Ze względu na posiadanie świadomości i wyższych zdolności kognitywnych, ludzka osoba rozumiana jest przez Ciorana jako istota tragiczna, przegrana w momencie narodzin, które wiąża się z koniecznością egzystowania w czasie i historii.

Choć powyższe przykłady - specyficzne dla wielu nurtów literatury i filozofii XX wieku - wyrastały głównie w oparciu o doświadczenie subiektywne, część teologów od dłuższego czasu dostrzega, że problematyka sensu, wyłaniająca się z filozofii podmiotu, stanowi poważne wyzwanie dla teologii. Wydaje się to o tyle istotne, ponieważ intuicje niektórych myślicieli humanistycznych nie sa tutaj dalekie od inspirowanych naturalizmem filozofii ewolucjonistycznych. Według Tomáša Halika doświadczenie absurdalnej i tragicznej strony ludzkiej rzeczywistości stanowi wręcz powód do podjęcia protestu przeciwko jednostronnej wizji chrześcijaństwa, w której akcentuje się tylko harmonię i rozumny ład w przyrodzie oraz historii ${ }^{76}$. Niektórzy, jak Dietrich Bonhoeffer skłonni byli nawet do podjęcia krytyki religijnej wizji świata, zastępując koncepcję Boga metafizyki Bogiem spotkania, wyłaniającym się z doświadczenia etycznego ${ }^{77}$. Co ciekawe, w ostatnich latach usiłuje się także konstruować teologię trynitarną w oparciu o wizję Boga obecnego w ewoluującym świecie ${ }^{78}$, który ma być gwarantem sensu w świecie stwarzanym poprzez przypadki i prawa.

74 J. Améry, O starzeniu się: Bunt i rezygnacja. Podnieść na siebie rękę: Dyskurs o dobrowolnej śmierci, tłum. B. Baran, Warszawa 2007, s. 145.

75 E. Cioran, Upadek w czas, tłum. I. Kania, Warszawa 2008, s. 17.

76 T. Halik, Teatr dla aniołów. Życie jako religijny eksperyment, tłum. A. Babuchowski, Kraków 2011, s. 17-18.

77 Zob. np. D. Bonhoeffer, Wybór pism, tłum. A. Morawska, Warszawa 1970, s. 272 .

78 D. Edwards, Bóg ewolucji. Teologia trynitarna, tłum. Ł. Kwiatek, Kraków 2016. 
Chrześcijańska antropologia akcentuje szczególny status i wartość ludzkiego życia. Według Romana Guardiniego „osoba posiada sens, który przekracza ciężar jej bytu" ${ }^{\prime 9}$. W świetle nauk ewolucyjnych o człowieku oraz filozofii naturalistycznej stanowisko to bywa jednak zdecydowanie krytykowane, a problematyka sensu ludzkiej egzystencji staje się miejscem, w którym filozofie inspirowane ewolucjonizmem stykają się z niektórymi propozycjami wysuwanymi w ramach humanistycznie rozumianej refleksji filozoficznej. Jeśli zatem teologowie będą chcieli prowadzić dziś dyskusję nad pytaniem o sens ludzkiej egzystencji, to zostaną zmuszeni do rewizji dotychczas podzielanej filozofii, stojącej przed wieloma wyzwaniami płynącymi ze strony nauk ewolucyjnych o człowieku, podważającymi - nierzadko na równi z humanistyką - koncepcję osoby jako istoty zajmującej w przyrodzie wyjątkową pozycję.

\section{Zamiast zakończenia}

W starożytności rozwój chrześcijańskiej doktryny był uzależniony nie tylko od wpływów i oddziaływań myśli żydowskiej, ale zwłaszcza od recepcji spuścizny klasycznej filozofii greckiej ${ }^{80}$. W wirze walk między ortodoksją a heterodoksją pierwszych wieków chrześcijaństwa ścierały się różne orientacje filozoficzne. Gwałtowne spory doktrynalne $\mathrm{w}$ obrębie religii szły równocześnie $\mathrm{w}$ parze $\mathrm{z}$ potrzebą dookreślenia wiary w kontekście pytań płynących z ówczesnej kultury. Język filozofii greckiej, uwrażliwiony na precyzję, zdawał się podnosić rangę chrześcijaństwa zarówno przed wykształconymi elitami, jak i gronem maluczkich, czyniąc z tej religii spójny system przekonań. Czy jednak obecnie teologowie skłonni są do podjęcia interpretacji chrześcijaństwa za pomocą narzędzi wyłaniających się z nowszej filozofii, otwartej na nauki szczegółowe?

79 R. Guardini, Koniec czasów nowożytnych. Świat i osoba. Wolność, taska, los, tłum. Z. Włodkowa, M. Turowicz, J. Bronowicz, Kraków 1969, s. 195.

80 Zob. np. J. N. D. Kelly, Początki doktryny chrześcijańskiej, tłum. J. Mrukówna, Warszawa 1988, s. 17-20, 23-28. 
Wczesnochrześcijańska teologia nie miała innego wyjścia, jak tylko kształtować się w oparciu o dostępne instrumentarium filozoficzne. Wiązało się to nierzadko z trudnościami. Nie będzie przesadne stwierdzenie, że źródła sporów chrystologicznych pierwszych wieków naszej ery brały się w dużej mierze $\mathrm{z}$ pomieszania między filozoficznymi terminami, które - zaprzęgnięte do potrzeb usystematyzowania doktryny religijnej - dopiero z czasem miały użyźnić glebę dla kiełkującej teologii. Biorąc pod uwagę te okoliczności nie trudno dziwić się, że stosunek chrześcijaństwa do myśli Greków od początku nie był jednoznacznie pozytywny. O ile w II wieku n.e. Justyn skłonny był uważać chrześcijaństwo wręcz za filozofię - i to „prawdziwa filozofię”! - o tyle w podobnym okresie Tacjan czy Hermiasz krytykowali kulturę i myśl grecka ${ }^{81}$. Można zastanawiać się, czy takie stanowisko było w pełni uzasadnione. Warto jednak zwrócić uwagę, że sprzeciw wobec poglądów filozofów niekoniecznie musiał wyrastać z irracjonalnych pobudek, lecz mógł stanowić efekt psychologicznie motywowanego dążenia do osiagnięcia wiedzy pewnej i niepodważalnej, której filozofia grecka po prostu skapiła; szczególnie wobec rozbieżności i niejednoznaczności stanowisk wśród filozofów trudno było zająć konkretne stanowisko ${ }^{82}$. Późniejsze dzieje chrześcijaństwa pokazały jednak, że obydwa punkty widzenia, tak Justyna, jak i Tacjana, często przenikały się ze sobą (choć gwoli ścisłości - niekiedy tendencje racjonalistyczne spychane były w cień na przykład przez prądy mistycyzujace). Nie zmienia to jednak faktu, że chrześcijaństwo pozostawało otwarte na spuściznę filozoficzna, która do czasów nowożytnych była de facto jedynym krytycznym, wręcz naukowym - choć nie w dzisiejszym sensie tego słowa - spojrzeniem na rzeczywistość.

Obecnie szeroko rozumiana teologia chrześcijańska zdaje się tkwić w poważnym kryzysie. Jest to kryzys częściowo wyrastajacy z obawy przed utratą ugruntowanego, pewnego podłoża, jaki proponowała akceptowana dotychczas - zwłaszcza w teologii

81 Zob. F. Drączkowski, Patrologia, Pelplin-Lublin 2007, s. 66-74.

82 Zob. np. Hermiasz, Satyra na filozofów pogańskich, tłum. L. Misiarczyk, w: Pierwsi apologeci greccy, tłum. L. Misiarczyk, Kraków 2004, s. 501-511. 
katolickiej - „filozofia wieczysta”, czyli tomizm. Myśl współczesna jawi się wielu teologom jako niekonkluzywna i zbyt hipotetyczna. Obawy Tacjana, który krytykował filozofię grecką za jej pluralizm, spekulatywność i zmienny charakter, powracają we współczesnych dyskusjach nad filozoficznymi źródłami teologii. Warto wobec tego przypomnieć, że choć:

1) nie istnieje chrześcijańska teologia pozbawiona podstaw metafizycznych, to równocześnie

2) nie istnieje jedna i ostateczna postać metafizyki, rozumianej jako system lub określone nastawienie teoretyczne,

3) nie istnieje jednolita i wewnętrznie spójna teologia chrześcijańska, zarówno ze względu na różnice wyznaniowe, jak i z powodu różnych tendencji i nastawień w obrębie teologii wyznaniowych ${ }^{83}$.

Powyższe założenia wskazywałyby na potrzebę większego pluralizmu w obrębie dociekań teologicznych. Według Hellera zadaniem teologii byłoby zatem przyjęcie dzisiejszego obrazu świata, wyłaniajacego się z nauki (z uwzględnieniem zmiennego charakteru naukowej wizji rzeczywistości ${ }^{84}$ ), a równocześnie prowadzenie teologicznego namysłu nad nauką (teologia nauki ${ }^{85}$ ) w kontekście wyników pochodzacych z poznania specyficznego dla filozofii przyrody, filozofii nauki i nauk formalnych. Heller nawiązuje w związku z tym do obecnej w teologii fundamentalnej kategorii wiarygodności: „Jeżeli teologia ma zdobyć wiarygodność w oczach dzisiejszego wykształconego człowieka, to musi się mu przedstawić jako racjonalnie zorganizowane poznanie, czyli w tej warstwie, która łączy ją z naukami, powinna

${ }^{83}$ Zob. K. Śnieżyński, Metafizyka $w$ teologii. Metafizyczne instrumentarium w myśli teologicznej Dietricha Bonhoeffera, Karla Rahnera, Eberharda Jüngela, Poznań 2008, s. 60-61.

${ }_{84}$ Zob. M. Heller, Naukowy obraz świata a zadanie teologa, w: Obrazy świata w teologii i w naukach przyrodniczych, red. M. Heller, S. Budzik, S. Wszołek, Tarnów 1996.

85 Zob. M. Heller, Nowa fizyka i nowa teologia, Tarnów 1992; J. Życiński, W poszukiwaniu teologii nauki, w: Nauka-religia-dzieje: II Seminarium Interdyscyplinarne w Castel Gandolfo, 6-9 września 1982 roku, red. J. A. Janik, P. Lenartowicz, Kraków 1984, s. 80-85. Obecnie podejmuje się próbę projektowania teologii nauki jako nowej dyscypliny teologicznej. Zob. Teologia nauki, red. J. Mączka, P. Urbańczyk, Kraków 2015. 
stosować te same metody, co one. Ale pod sankcją utraty swojej identyczności musi także zachować własną specyfikę", mając przy tym świadomość, „że obszar dostępny ludzkiej racjonalności nie pokrywa się z cała rzeczywistościa, albo [...] że granice ludzkiej racjonalności nie pokrywają się z granicami racjonalności w ogóle" ${ }^{86}$. Tak rozumiana teologia mogłaby zapewne wzbogacić - również dzięki nawiązaniu do wyników nauk ewolucyjnych o człowieku - własne obszary refleksji związane z koncepcją osoby, wolności czy odpowiedzialności, co skłaniałoby równocześnie do ponownego przemyślenia bardzo wielu zróżnicowanych kwestii z zakresu dogmatyki i teologii moralnej, począwszy od pojęcia osoby i teorii działania ludzkiego, aż po tak złożone zagadnienia, jak grzech pierworodny czy problem apokatastazy (rozumiany obecnie częściej pod postacia sporu dotyczacego nadziei powszechnego zbawienia).

Czy jednak stanowisko Hellera uznać można dziś za dostatecznie uzasadnione? Czy teologowie maja jeszcze coś istotnego do powiedzenia na temat otaczającego nas świata? Czy sama idea Boga nie jawi się dziś - chociażby w świetle niektórych badań z zakresu psychologii $^{87}$ - wyłącznie jako wytwór naszego umysłu, zmieniajaccy się zależnie od potrzeb człowieka ${ }^{88}$ ? A wreszcie: czy chrześcijańscy uczeni są w stanie zaproponować taką koncepcję natury ludzkiej, która miałaby szansę sprostać wyzwaniom stawianym przez ewolucjonizm? W kontekście przeprowadzonych analiz wydaje się, że teologia boryka się obecnie z ogromnymi trudnościami w tym zakresie. Przypuszczalnie przestrzenią ewentualnego dialogu między naukowym a teologicznym obrazem człowieka będzie filozofia, która docieka nie tylko istoty Homo sapiens jako specyficznego gatunku zwierzęcego (rozważając przy tym pytania dotyczące sensu/bezsensu egzystencji poszczególnych jednostek), ale również podejmuje refleksję nad nauką (czy szerzej - jest obecna w naukach) i stanowi podstawę

86 M. Heller, Teologia dzisiaj - detronizowanie królowej? [lectio magistralis ks. prof. Michała Hellera], „Vita Academica” 88/3 (2016), s. 9.

87 Zob. np. J. A. Thomson, Dlaczego wierzymy w boga(-ów). Krótki przewodnik po nauce o wierze, tłum. D. Jamrozowicz, Nysa 2013.

88 Zob. np. K. Armstrong, Historia Boga. 4000 lat dziejów Boga w judaizmie, chrześcijaństwie $i$ islamie, tłum. B. Cendrowska, Warszawa 1996. 
dla rozumowań w teologii. Jeśli natomiast teologowie podejmą już namysł nad problematyka osoby w nawiązaniu do ewolucjonizmu, to prędzej czy później natkną się również na pytania generowane przez współczesną humanistykę, świadczące o potrzebie prowadzenia badań w duchu interdyscyplinarnym, uwzględniającym specyfikę różnych sposobów poznawania. Czy doprowadzi to do sytuacji, w której antropologia stanie się miejscem zbliżenia dwóch kultur, o których pisał swego czasu Charles Percy Snow? ${ }^{89}$ Wydaje się, że na odpowiedź przyjdzie jeszcze poczekać, niemniej wyzwanie ze strony nauki zostało już rzucone.

\section{Summary}

\section{A unique position of man in nature? Evolutionary sciences and Christian anthropology}

The article discusses the problem of the christian concept of the human person in theological and philosophical context, and with reference to evolutionary sciences. It was pointed out that the naturalistic evolutionism undermines the most important assumptions (especially thesis proclaiming the unique status of human in nature), which is based on christian anthropology. In this paper it was also an attempt to justify that philosophical reflection can be important in the analysis of problems located between science and religion (among others the issue of the origin, nature and destiny of man). The question about new type of christian philosophy is a challenge in theology, which will be obliged because of the changing image of the world and man - to modify its foundations, rooted mainly in the Thomistic metaphysics so far. Besides, in the context of issues relating to the meaning of human life it indicates that there is a need to develop such a philosophy, which is based on the achievements of natural science, and would be in dialogue with the contemporary humanities.

Keywords: anthropology, human, person, evolutionism, naturalism, Christian philosophy, science-religion.

89 Zob. C.P. Snow, Dwie kultury, tłum. T. Baszniak, Warszawa 1999, s. 79-81. 


\section{Bibliografia}

Améry J., O starzeniu się: Bunt i rezygnacja. Podnieść na siebie rękę: Dyskurs o dobrowolnej śmierci, tłum. B. Baran, Warszawa 2007.

Améry J., Poza wina i kara. Próby przełamania podjęte przez złamanego, tłum. R. Turczyn, Kraków 2007.

Armstrong K., Historia Boga. 4000 lat dziejów Boga w judaizmie, chrześcijaństwie $i$ islamie, tłum. B. Cendrowska, Warszawa 1996.

Atran S., Ewolucyjny krajobraz religii, tłum. M. Kolan. Kraków 2013.

Barth G., Ku całościowej wizji osoby ludzkiej. Metodologiczne założenia personalizmu chrześcijańskiego, „Teologia w Polsce” 2/1 (2008), s. 43-53.

Bonhoeffer D., Wybór pism, tłum. A. Morawska, Warszawa 1970.

Boyer P., I człowiek stworzył bogów... Jak powstała religia?, tłum. K. Szeżyńska-Maćkowiak, Poznań 2001.

Bremer J., Czy wolna wola jest wolna? Kompatybilizm na tle badań interdyscyplinarnych, Kraków 2013.

Buss D., Psychologia ewolucyjna, tłum. M. Orski, Gdańsk 2001.

Chodasewicz K., Definiować czy nie? Wspótczesne kontrowersje na temat potrzeby i sposobu definiowania życia, „Kosmos” 63/4 (2014), s. 501-516.

Cioran E., Upadek w czas, tłum. I. Kania, Warszawa 2008.

Clements T., Nauka kontra religia, tłum. B. Stanosz, Warszawa 2002.

Crick F., Zdumiewajaca hipoteza, czyli nauka w poszukiwaniu duszy, tłum. B. Chacińska-Abrahamowicz, M. Abrahamowicz, Warszawa 1997.

Damasio A., Bład Kartezjusza, tłum. M. Karpiński, Poznań 1999.

Danel D., Psychologia ewolucyjna - nauka o adaptacjach i ewolucyjnej inercji ludzkiego umystu, „Kosmos” 58/3-4 (2009), s. 574-576.

Dawkins R., Apetyt na cuda. Przepis na uczonego, tłum. P. J. Szwajcer, Warszawa-Stare Groszki 2016.

Dawkins R., Samolubny gen, tłum. M. Skoneczny, Warszawa 1996.

Dawkins R., Ślepy zegarmistrz, czyli jak ewolucja dowodzi, że świat nie został zaplanowany, tłum. A. Hoffman, Warszawa 1994.

Dekret o formacji kapłańskiej „Optatam Totius”. 
Dennett D., Odczarowanie. Religia jako zjawisko naturalne, tłum. B. Stanosz, Warszawa 2008.

Drączkowski F., Patrologia, Pelplin-Lublin 2007.

Edwards D., Bóg ewolucji. Teologia trynitarna, tłum. Ł. Kwiatek, Kraków 2016.

Flew A., Theology and Falsification, w: Reason and Responsibility: Readings in Some Basic Problems of Philosophy, eds. J. Feinberg, Belmont 1968, s. $48-49$.

Fothergill P. G., Chrześcijanie wobec ewolucji, tłum. T. Górski, Warszawa 1966.

Frankl V. E., Człowiek w poszukiwaniu sensu, tłum. A. Wolnicka, Warszawa 2009.

Gazzaniga M., The Ethical Brain: The Science of Our Moral Dilemmas, New York-Washington 2005.

Gazzaniga M., The Social Brain: Discovering the Networks of The Mind, New York 1985.

Granat W., Personalizm chrześcijański. Teologia osoby ludzkiej, Poznań 1985.

Guardini R., Koniec czasów nowożytnych. Świat i osoba. Wolność, łaska, los, tłum. Z. Włodkowa, M. Turowicz, J. Bronowicz, Kraków 1969.

Halik T., Teatr dla aniołów. Życie jako religijny eksperyment, tłum. A. Babuchowski, Kraków 2011.

Heller M., Jak możliwa jest „filozofia w nauce”?, „Studia Philosophiae Christianae" 22/1 (1986), s. 7-19.

Heller M., Czy istnieje autentyczna filozofia przyrody?, „Studia Philosophiae Christianae" 23/1 (1987), s. 5-20.

Heller M., Naukowy obraz świata a zadanie teologa, w: Obrazy świata w teologii i $w$ naukach przyrodniczych, red. M. Heller, S. Budzik, S. Wszołek, Tarnów 1996.

Heller M., Nowa fizyka i nowa teologia, Tarnów 1992.

Heller M., Sens życia i sens Wszechświata. Studia z teologii wspótczesnej, Tarnów 2002.

Heller M., Teologia dzisiaj - detronizowanie królowej? [lectio magistralis ks. prof. Michała Hellera], „Vita Academica” 88/3 (2016).

Heller M., Liana Z., Mączka J., Skoczny W., Nauki przyrodnicze a teologia: konflikt i wspótistnienie, Tarnów 2001. 
Heller M., Życiński J., Epistemologiczne aspekty zwiazków filozofii z nauka, w: Filozofować w kontekście nauki, red. M. Heller, A. Michalik, J. Życiński, Kraków 1987, s. 9-15.

Hermiasz, Satyra na filozofów pogańskich, w: Pierwsi apologeci greccy, tłum. L. Misiarczyk, Kraków 2004.

Jan Paweł II, Fides et ratio.

Jestem nihilista, bo wcia $\dot{z}$ wierze $w$ prawdę. $Z$ Rayem Brassierem rozmawia Marcin Rychter, „Kronos” 16/1 (2011).

Kahneman D., Pułapki myślenia. O myśleniu szybkim i wolnym, tłum. P. Szymczak, Poznań 2011.

Kelly J. N. D., Poczatki doktryny chrześcijańskiej, tłum. J. Mrukówna, Warszawa 1988.

Konarzewski M., Ewolucja natury ludzkiej, „Archeus” 7 (2006).

Kuczyński T., Człowiek - twór przyrody czy coś więcej?, Płock 2015.

Kuhn T., Struktura rewolucji naukowych, tłum. H. Ostromęcka, Warszawa 2001.

Marek-Bieniasz A., Richarda Dawkinsa geocentryczna interpretacja ewolucji i jej zasadność. Analiza krytyczna, Częstochowa 2008.

Mayr E., To jest biologia. Nauka o świecie ożywionym, tłum. J. Szacki, Warszawa 2002.

McGrath A., Nauka i religia, tłum. M. Chojnacki, Kraków 2009.

Mikucki K., Tomizm w Polsce po II wojnie światowej, Kraków 2015.

Minois G., Kościót i nauka. Dzieje pewnego nieporozumienia. Od Augustyna do Galileusza, tłum. A. Szymanowski, Warszawa 1995.

Minois G., Kościót i nauka. Dzieje pewnego nieporozumienia. Od Galileusza do Jana Pawła II, tłum. A. Szymanowski, Warszawa 1996.

Monod J., Przypadek i konieczność. Esej o filozofii biologii wspótczesnej, tłum. J. Bukowski, Warszawa 1979.

Naukowa koncepcja świata. Koło Wiedeńskie, red. H. Hahn, O. Neurath, R. Carnap, tłum. A. Koterski, w: Naukowa koncepcja świata. Koło Wiedeńskie, red. L. Brogowski, Gdańsk 2010.

Paul J., Mowa wypowiedziana przez umartego Chrystusa ze szczytu kosmicznego gmachu o tym, że nie ma Boga, „Kronos” 16/1 (2011). 
Pawlicki S., Studyja nad darwinizmem, Kraków 1875.

Pedersen O., Konflikt czy symbioza? Z dziejów relacji między nauka a teologia, tłum. W. Skoczny, Tarnów 1997.

Pinker S., Tabula rasa. Spory o naturę ludzka, tłum. A. Nowak, Gdańsk 2012.

Pius XII, Encyklika „Humani Generis”.

Rusecki M., Istota i geneza religii, Lublin-Sandomierz 1997.

Seweryniak H., Teologia fundamentalna, t. 1, Warszawa 2010.

Słomka M., Ewolucjonizm chrześcijański. O pochodzeniu człowieka, Lublin 2004.

Snow C.P., Dwie kultury, tłum. T. Baszniak, Warszawa 1999.

Stewart-Williams S., Darwin, Bóg $i$ sens życia, tłum. P. J. Szwajcer, Stare Groszki 2014.

Szary S., Człowiek - podmiot dramatu. Antropologiczne aspekty filozofii dramatu Józefa Tischnera, Kęty 2005.

Śnieżyński K., Metafizyka $w$ teologii. Metafizyczne instrumentarium w myśli teologicznej Dietricha Bonhoeffera, Karla Rahnera, Eberharda Jüngela, Poznań 2008.

Teologia nauki, red. J. Mączka, P. Urbańczyk, Kraków 2015.

Thomson J. A., Dlaczego wierzymy w boga(-ów). Krótki przewodnik po nauce o wierze, tłum. D. Jamrozowicz, Nysa 2013.

Tischner J., Filozofia dramatu, Kraków 2006.

Tischner J., Schytek chrześcijaństwa tomistycznego, „Znak” 187/1 (1970).

Vagaggini C., Teologia. Pluralizm teologiczny, tłum. J. Partyka, Kraków 2005.

Warzeszak J., Człowiek w obliczu Boga i pośród stworzenia, Warszawa 2005.

Weiner J., Hipotezy o powstaniu i wczesnej ewolucji życia, „Kosmos” 58/3-4 (2009), s. 501-528.

Wencel K. T., Traktat o człowieku, w: Dogmatyka, t. 5, Warszawa 2007, s. 15174.

Wilson D. S., Darwin's Cathedral: Evolution, Religion, and the Nature of Society, Chicago 2002.

Wilson E. O., O naturze ludzkiej, tłum. B. Szacka, Warszawa 1988. 
Wilson E. O., Konsiliencja. Jedność wiedzy, tłum. J. Mikos, Poznań 2011.

Wojciechowski T., Wybrane zagadnienia z filozoficznej antropologii, Kraków 1985.

Wright R., Moralne zwierzę. Dlaczego jesteśmy tacy, a nie inni. Psychologia ewolucyjna a życie codzienne, tłum. H. Jankowska, Warszawa 2003.

Zaborski W., Darwinizm wobec rozumu i nauki, Kraków 1886.

Życiński J., Bóg i ewolucja. Podstawowe pytania ewolucjonizmu chrześcijańskiego, Lublin 2002.

Życiński J., Bóg i stworzenie. Zarys teorii ewolucji, Lublin 2011.

Życiński J., Granice racjonalności. Eseje z filozofii nauki, Warszawa 1993.

Życiński J., W poszukiwaniu teologii nauki, w: Nauka-religia-dzieje: II Seminarium Interdyscyplinarne w Castel Gandolfo, 6-9 września 1982 roku, red. J. A. Janik, P. Lenartowicz, Kraków 1984, s. 80-85.

Życiński J., Wszechświat emergentny. Bóg w ewolucji przyrody, Lublin 2009. 